LINGUACULTURE 1, 2018

\title{
BETWEEN EAST AND WEST: ENGLISH AS THE LANGUAGE OF ESCAPE IN COMMUNIST ROMANIA
}

\author{
DANIELA DoBoș ${ }^{*}$ \\ Alexandru Ioan Cuza University of Iaşi, Romania
}

\begin{abstract}
At the start of the 21st century, the status of English is as controversial as ever, given the current linguistic situation of widespread linguistic loss and the emergence of English as a preeminent language - a world language, an international language, a global language or a lingua franca in almost all settings (Graddol, 1997, 2006; Seidlhofer, Crystal), i.e. a much (over)-used vehicular language. It can easily be argued that no other language ever has been as hotly debated as English, which I would call a "commodity". To the list of qualifiers that have been assigned to English I would add "escape", which I would argue is the role English assumed behind the Iron Curtain. Based on my own experience as a teenager in communist Romania, as well as evidence from various memoirs published following the collapse of the regime in 1989, the paper argues that, more than just a symbol of freedom, in communist Romania, the role of English was clearly that of escape from the ideological pressures and widespread fear, as well as the degraded and degrading everyday reality.
\end{abstract}

Keywords: communism; the role of English; English teaching; rock music; translation.

"Socialism is the same as Communism, only better English." George Bernard Shaw

In the context in which the collective memory of the communist past in Romania is disappearing fast, as the language of the mass media is taking over while people are now mistaking the hiperreality of television for their own lives, it is of crucial importance to preserve bits of this memory that can

*dana.dobos@uaic.ro 
help document spiritual life during that era. On the other hand, as Adam Burakowski argues, the history of communism in Romania still holds many secrets, while many important issued have not been researched yet (Burakowski 15). It is in this sense that this paper brings together the East, that is communist Romania, and the West, in this case the English language and culture. This paper argues that English played a subversive role in Romania behind the Iron Curtain.

\section{THE STATUS OF ENGLISH}

Currently, the status of English is as controversial as ever, given the current situation of widespread linguistic loss and the emergence of English as a preeminent language - a world language, an international language, a global language or a lingua franca in almost all settings (Graddol, 1997, 2006; Seidlhofer, 2001; Crystal, 2003), i.e. a much (over)-used vehicular language. It can easily be argued that no other language has ever been as hotly debated as English, which I would call a "commodity". Basically, the debates could be broadly summarized by borrowing Kachru's (1996) terms: the "agony" vs. the "ecstasy" of English. What many theorists seem to forget or ignore is that English, like any other language is neutral, "a mere parasitic species at the mercy of [its] creators and hosts" (Mufwene 2001); rather, it is speakers who make languages serve their needs since, as Bourdieu has shown, language behaviour is profit-driven.

In an engaging feature exploring how English and other languages might be related to development, linguist Alastair Pennycook ("Development, culture and language" 5) argues that we have to see English as an international language in terms of the cultural identities it offers its speakers, and discusses six frameworks (possible understandings) of English in the world: colonial celebratory, laissez-faire liberalism, modernization, imperialism, linguistic hybridity and postcolonial performativity.

The 'colonial-celebratory' framing, deemed to be extremely popular, "trumpets the benefits of English over other languages, suggesting that it has both intrinsic and extrinsic qualities superior to other languages, while allowing no place for a sense of diversity". The second framing, 'modernization', sees the significance of English less in terms of inherent internal qualities and more in terms of the roles that English is deemed to play in the process of development and modernization. English is here assumed to be a language that is better suited for modern use, for science, technology and global communication. This "pernicious dichotomy" needs to be resisted, according to others, "if other languages are to be given a chance" ("Development, culture and language" 6). This construction of English, Pennycook argues, is "constantly bolstered by images of English 
that associate it with computers, technology, science, tourism, diplomacy, internationalisation, globalisation, modern financial markets, the internet, elearning, whatever is new", but any such connections "need to be demonstrated not assumed, and the role of English in potentially changing people's lives must be seen in the context of the potential harms it may bring to other languages, and the role it may play in the reproduction of inequality".

'Laissez-faire liberalism', the most common framing, tends to take a more 'neutral' line, as exemplified by David Crystal's "globally marketed book on the global spread of English", which "tries to argue for a complementarity between a support for the benefits of English as a global means of communication and the importance of multilingualism", for a balance between the dual values of "international intelligibility" and "historical identity". Reviewing Crystal's book, John Hanson, former director-general of the British Council, argues that the spread of English is the result of "countless millions of acts of choice, by students, teachers, employers and the employed, who have no interest in the health, future, spread, or whatever of the English language. What 'drives' them is a view of their job prospects, their relationship with the rest of the world, their excitement in youth culture, a wish to be insiders, to be in touch" ("Development, culture and language” 7). Liberal laissez-faire views are inadequate, Pennycook argues, because they fail to account for the power of English and thus the inequitable relationship between English and local languages. Such liberal views, which emphasize personal choice, neutrality and complementarity are seen by Pennycook as potentially the most dangerous of these three paradigms.

In trying to find a possible way of thinking about English that acknowledges the significance of all the perspectives mentioned above, Pennycook ("Development, culture and language" 10) suggests the notion of 'postcolonial performativity', noting that we need both a political understanding of the global role of English and a means to understand contextually how English is used, taken up, and changed. Postcolonial performativity suggests that to understand what role English plays in particular contexts we need specific sociologies of these contexts. Also, Claire Kramsch (1993) writes that we need to start thinking of what is produced in cultural encounters, not just homogeneity or heterogeneity, imperialism or resistance, but rather what 'third cultures' or 'third spaces' are constantly being created.

Taking up Pennycook's suggestion that in order to understand the role played by language at any one time one ought to consider the sociology of the context in question, the framework of analysis that appears to be suitable for this paper appears to be that of language and ideology. Chronologically 
however, the first thing worth noting is that English was a latecomer in the field of foreign language studies in Romania, having emerged in the early 1800s in a largely "francophone" country (Vianu). At the beginning of the $20^{\text {th }}$ century, several English self-study textbooks printed in French were in use, which had been brought by the French and Belgian engineers employed by the British and American oil companies operating in Romania. After quoting Maurice Pearton -"Britain and Romania were never able to regard each other squarely till December 1989", Dumitru Dorobăţ gives the following explanation for this delay: "The complicated politics of the relationship between Britain and the various geo-political bodies with which Romania was lumped at different times partially accounts for the reluctance with which the institutionalization of English Studies met initially" (Dorobăţ $11)$.

\section{ENGLISH IN ROMANIA}

The first English chair in Romania was set up by Petre Grimm at the University of Cluj in November of 1919; however, in the summer of the same year, the Ministry of Public Instruction had requested the approval of the Senate of the University of Iaşi to set up an English chair (Doboş 131). The request was approved on condition that it be occupied by "an academic from England”, a requirement that could not be fulfilled for a long time. Thus at the University of Iaşi the first professor of English was Iancu Botez, appointed in January of 1926, before which he had taught at several commercial secondary schools,"the only schools in Romania at the time where English was a subject in the curriculum" (Dorobăţ 14).

The English chair in Chernowitz took precedence, being set up in 1904. Dragoş Protopopescu was the first tenured professor in 1925. In October 1940 Protopopescu was transferred to the English chair at the University of Bucharest, where he taught Shakespeare and the English Drama. Following the imposition of communist rule, he was dismissed from his post, and in order to avoid being arrested he committed suicide in 1948. During communism his name was obscured, but his former distinguished students Ana Cartianu, Leon Leviţchi, Dan Duţescu, Zoe Dumitrescu-Buşulenga, Antoaneta Ralian and Mihail Bogdan carried on his work while not letting his name be forgotten, despite the fact that it could not be brought up in public. In his last published book of 1947, Gramatica vie a limbei engleze, Protopopescu singled out five identifying features of English, i.e. its "vitality", as reflected in its extremely rich vocabulary, an attraction for linguistic innovations and its word-formation techniques; its "harshness/toughness" as indicated by its fricative consonants and phonetic stresses, which also reflect its moral force; "practicality", "the only logic of 
English and since grammar is not always practical, English sacrifices it in cold blood"; "finesse", as English is spoken softly, disfavours diminutives, uses negation more than affirmation and embraces euphemisms; and its "ambiguity", as related to phonetic stress and as shown by the several grammatical functions of $a$, the, all, as well as word polysemy. Leon Leviţchi writes that Petre Grimm, Dragoș Protopopescu, Ioan Botez and Marcu Beza were the first Romanian anglicists who published studies and research without French or German intermediary literature (Leviţchi 6).

The year 1948 was a fateful year not only for private property, but for foreign languages as well, as the Education Act, which ironically emphasized the importance of foreign language learning, in fact created the legal framework for the politicization of education. It was also the year when the last two students graduated from the Department of English of the University of Iaşi, following its disbandment. English was decreed "an imperialistic language" and literally imprisoned, as in 1950 the Associated Press Bureau in Romania was closed down and its director, a Romanian citizen, was tortured before receiving a 25-year prison sentence. All those who had any relationship with the British and American Libraries and Press Offices were also arrested (Urma 116). In the early 1950s the only English Department left in Romania was that in Bucharest, with fewer than 20 students in 1952. Russian had become compulsory.

The communist regime and its dis-braining ideology were firmly established in the mid-20th century and the ensuing terror and political crimes are now fully documented, mainly in the hundreds of memoirs of survivors. Ceauşescu's regime was the most oppressive and autocratic of the entire Eastern bloc, wielding violence not only on the people but also on their habitats, towns and villages, including the national history. A major aim, as is well known, was the creation of "the new man"/ homo sovieticus, who had no use for foreign languages, or indeed anything coming from the West. "Socialist realism" became the norm in arts, science and education involving, among other things, the import of violence in literature while "cosmopolitanism" became a serious crime.

As is known, all societies tend to reject the effects of ideology so that there will always be tendencies of subversion. Poet and translator Gabriel H. Decuble describes what he calls "the incarcerated society": "when ideology becomes stifling, when the totalitarian state relies on it to annihilate public life, which becomes marked by insecurity and generalized suspicion, then social life recedes within the family or a limited group of friends [...]. In order to preserve a semblance of humaneness, society will develop strategies of self-defence, such as political humour. Not only language - striving to avoid the communist Newspeak - is contrived in such a society, but also the meaningful gestures and objects (representations of reality) and everything 
that makes up the social environment” (Decuble 7). Historians and dissidents have debated the freedom options of citizens trapped behind the former Iron Curtain, including that of being an "internal emigrant" (Churchward 137); it has been argued that it was always possible to preserve one's freedom of conscience even under the direst tyranny.

Communism in Romania can be divided up into three distinct stages 1946 - 1964: Stalinization involving the wiping away of the old social order; 1964 - 1971: barely a decade of de-Stalinization and liberalization, and finally the last two decades of re-Stalinization and depredations. English in Romania followed the whims of politics, reacting to the varying intensity of ideological pressure. Thus the first period involved the reshaping of education on the Soviet model, including the all-important compulsory study of Marxism-Leninism and Russian which, with 3hs/ week in higher education replaced the "imperialistic" languages. Mihai Ralea for instance deemed Soviet culture as superior to the Western cultures (Ralea 144). It was the time when the former values were destroyed and intellectuals were dismissed and forced into degrading unskilled jobs (Bîtfoi 2012), while English, in its escape role, was taught in the political prisons, "the Penitentiary Academy". The former foreign minister, economist Mihail Manoilescu, taught it to his fellow inmates inside the Jilava penitentiary, as did writer Nicolae Steinhardt and Puiu Vojen, who taught Shakespeare. The English and French Libraries in Bucharest were deemed spy nests so the students who frequented them looking for intellectual escape were commonly arrested and sent to work colonies (see, for example Costin 4748; 107). At that time learning English was a criminal act, an example being included in Alexandru Ivasiuc's largely autobiographical novel Interval, where a young woman is exposed at a young communist student meeting for learning English and is consequently expelled from the university. This was the time when English clearly became a liability. On the other hand, the children of the "nomenclatură", most of them working class, had private English tutoring (Tismăneanu 86).

At the end of the 1950s the door was cracked open for English studies: Leon Leviţchi authored the first English grammar for Romanians, Gramatica limbii engleze (1958) (the first after Protopopescu's 1947 grammar), followed in 1959 by the first edition of what was to become a very popular textbook, Învăţaţi limba engleză fără profesor (Teach Yourself English) (with Dan Duţescu). English culture too was bravely represented by Shakespeare, whose works were translated and published in twelve volumes at ESPLA Publishing House between 1955 and 1963. Mihnea Gheorghiu's foreword to the first volume however turned Shakespeare into a proletarian and propagandist, as Volceanov rightly argues, an author of "progressive, realist literature, close to the entire people's aspirations” (Volceanov 5), and 
worried about "the rising of the bourgeoisie and the monarchy plundering the toiling masses". This was Shakespeare "the party card holder", fighter for a better world (Volceanov 18-24). Besides Shakespeare, Leviţchi published numerous translations beginning in the 1940s and 50s (Leviţchi 11-12). (For a history of The British Council in Romania which reads like a thriller, see Deletant 2013).

\section{THE 1960s}

The 1960s were a period of liberalization and unprecedented freedom, a very dynamic decade when national culture strove to reconnect with its pre-war roots while feverishly assimilating Western influences. During this very dynamic decade English Studies were established to really thrive (Leviţchi 6) and English itself came to the fore just in time to support the newly established contacts with various cultural experiments, including the American counter-culture.

In 1968 a new education law was passed which strove to revive the traditions of Romanian education besides purportedly taking inspiration from Western pedagogy, so that foreign languages began to be taught as early as the second grade of primary schools. In 1963, when in Moldavia there were only two secondary schools where English was taught, the Department of English of the University of Iaşi was re-opened following the establishment of embassies in both countries. Because the teaching resources were scarce, the first teaching staff, including Professor Viorica Dobrovici, compiled textbooks and translations besides setting up the first language laboratory (Dorobăț 18). Contacts began to be established with Western universities. English lessons began to be were broadcast on the radio and television for a wide audience.

In terms of textbooks for learning English, the 1960s were by far the best decade. In 1962 the People's University in Bucharest (Universitatea populară) set up foreign language classes which attracted large numbers of people; to this end the teaching staff (V. Ştefănescu-Drăgăneşti, A. Nicolescu and V. Hanea) compiled three remarkable sizeable textbooks, Limba engleză. Curs practic, beginner through advanced - the first volume in 1969, the second in 1972 and the third in 1973. Editura Didactică şi Pedagogică published Mariana Raţiu's excellent English Reader, 3 small format volumes, for young learners; in fact throughout the decade and into the 1970s, this publishing house put out a large number of books of classical English literature, featuring footnotes, vocabulary explanations and prefaces. "The popularity of English among children and their parents was reflected in the competition for places to study English at universities", writes Deletant (Deletant 28), so that The British Council increased its provision of English 
language lecturers and books to higher education institutions and to the English language secondary school in Cluj.

In 1961 a catalyst for the popularity of rock music and the English language among the young generation was the movie The Young Ones featuring Cliff Richard and The Shadows, which strangely enough was screened for several months on end. In 1967, music critic Cornel Chiriac first broadcast what became the popular music programme Metronom before it was banned two years later after Chiriac aired the Beatles' Back in the USSR among other allusive songs following the Soviet invasion of Czechoslovakia. Following the screening of The Young Ones, the first Romanian rock bands were set up by college students - Phoenix (1962), Sfinx (1963), Olympic'64, Sincron (1964) and in Iaşi Meteor (1965). The word "rock" was still proscribed, so they called themselves "electric guitar bands”. Olympic '64's guitarist, Dimitrie Inglessis, started by phonetically re-writing the Beatles' lyrics into Romanian, so that their sound was very similar, e.g. Ogarul vs Oh, Carol, Elin oribil vs Eleanor Rigby or Ştiu bine, gard des $n$-ai vs It's Been A Hard Day's Night (interview by Cornel Ionescu in Ionescu 2011: 46). "Stalinist cultural policy of course proscribed the decadent sounds of corrupt capitalism", however "throughout the sixties and seventies rock music became a rallying point for young people disaffected by their communist elders. Although most Warsaw Pact nations followed a similar cycle of tolerance and suppression, the most responsive to their young people were Poland and Hungary, while Romania and Bulgaria cracked down the hardest” (kirkus reviews.com).

Poet and translator Mihai Cantuniari writes in his memoir: "Living in the 60s was great. It was great even in Romania, despite the alien ideology that had been forced on us. [...] All Ray, Pat, Chuck, Fats or the four Beatles had to do was open their mouths for the latest party and state directives to be reduced to dust” (Cantuniari 290-292). For writer and academic Mircea Cărtărescu, the Beatles were highly poetic: “it wasn't just astonishing music, it was the poetry I wanted to write, the psychedelic fragrances my mind cherished". In the 70s "we enjoyed, as best we could [...], our little Flower Power. Nobody believed in communism, everyone entered into the spirit of the age, noisy and exuberant. Time had not yet become impatient" (Cărtărescu 10). Literary critic Dan C. Mihăilescu writes that "as highschool students, the pop, rock, blues and folk invasion on the wavelengths of Radio Free Europe in the 1968-1972 Bucharest definitely established the perfect escape" (Mihăilescu 100).

For young people in 1960s Romania, English language pop and rock with their mythologies were a major escape, following Western popular counterculture which was a powerful trigger for change; such messages were carried in Europe by John Lennon's Revolution, Give Peace A Chance, 
Imagine and Woman Is the Nigger of the World and in the US by Bob Dylan's Like A Rolling Stone, The Times They Are A-Changin', A Hard Rain's A-Gonna Fall and many other 60s songs. In 1971 however, both electric guitars and English lyrics were proscribed. Songs, as music, derive their strength from the rhythm of the language and are essentially motivating, being one of the main reasons why young people throughout the world become interested in English. Often a common problem is that the words are indecipherable, drowned out by the music; however, they will usually be played and listened to repeatedly, so that both structures and phonetic patterns are likely to be internalized. (For the numerous cultural exchanges between Britain and Romania in the 1960s, see Townson).

For intellectuals, the 1960s opened up the West in terms of cultural and academic exchanges, including lectureships even in the U.S. Thus Vlad Georgescu, the first historian who was allowed to leave the country since 1944, taught South-Eastern European history at the University of Los Angeles in 1967 - 1968, and then in 1973 at Columbia University. In one of his reports written for the Securitate, he deemed the period between 1967 and 1974 to have been the best years of his life (qtd in Velimirovici 407). It was his good command of English which, besides his academic prowess, allowed him to go to Columbia, where he also published a book. English was the passport to freedom. Upon his return to Romania, however, he refused to collaborate with the Securitate and was professionally marginalized so that in 1976 he became a dissident. He was arrested and charged with high treason as the author of several incendiary texts, including a political pamplet satirizing the dictator, but was finally released and allowed to emigrate to the U.S. following concerted high level American intervention. His untimely death at the hands of the same dreaded Securitate while working at Radio Free Europe was only one more casualty.

\section{THE 1970s}

1971 was the momentous year when Nicolae Ceauşescu returned from his visit to China and North Korea and decided to transplant their cultural revolution to Romania as the notorious "July Theses", so that in a very short time a new iron curtain descended upon the country to brutally cut off all Western cultural influences. Party activists suddenly started to deplore the absence from literature and the arts in general of "the new man, builder of socialism and communism, carrier of the noblest ideals put forward by Marx, Engels and Lenin". Dan Hăulică’s radio programme "Vocile artei moderne", for example, came under severe criticism for its "hateful attitude, full of contempt for the working class" (Kerim 115-116). Next, at the $11^{\text {th }}$ Communist Party Congress in November of 1974, the dictator enforced the 
same principles on education, with the result that most secondary schools were turned into "industrial high schools" who would prepare skilled workers. By this move the number of higher education graduates was severely reduced. As a result, the number of foreign language classes was also reduced, as was the number of foreign language students. Young people at all education levels had to be "educated in the spirit of the revolutionary theory of the working class" (Buletinul Oficial al R.S.R nr.113, 26 decembrie 1978: 1-20). Re-stalinization continued throughout the 1980s.

Not surprisingly, the new English textbooks reflected the politicization of education. For example, the textbook for the $11^{\text {th }}$ grade $\left(7^{\text {th }}\right.$ year of study) from 1967 - 1970 (authors L. Leviţchi, I. Preda, V. Ştefănescu-Drăgăneşti \& M. Ţăranu) and that from 1973 - 1977 (authors S. Dörr, R. Surdulescu, C. Cojan \& A. Tănăsescu) couldn’t be more dissimilar, reflecting mainly the transformation of the former science and humanities secondary schools into industrial ones and the cut in the number of classes. The former contained 60 lessons based on English literature compared with the latter, which had 9 units plus the introductory one titled "To Be A Patriot", including an excerpt from Ceauşescu's "exposé on the political-ideological and culturaleducational activity of moulding the new man, a conscious and dedicated builder of the multilaterally developed socialist society and of communism in Romania" (S. Dörr, R. Surdulescu, C. Cojan \& A. Tănăsescu 5). The Programme of the Romanian Communist Party was a topic for oral and written compositions, while in the first unit the last exercise was a translation from the Ninth Party Congress Directives. Similar translations from political documents are found throughout the textbook. Similarly, the speaking practice topic in Revision III was "the organization and orientation of Romanian medical research in accordance with the line established by the documents of the $\mathrm{XI}^{\text {th }}$ Congress of the RCP” (S. Dörr, R. Surdulescu, C. Cojan \& A. Tănăsescu 158), while Revision IV included a translation exercise dealing with the communist party decision concerning the establishment of the sports competition "Daciada” (S. Dörr, R. Surdulescu, C. Cojan \& A. Tănăsescu 205).

In the same vein, the $12^{\text {th }}$ grade textbook ( $8^{\text {th }}$ year of study) (authors $\mathrm{S}$. Dörr, R. Surdulescu, M. Tatos) contained an Introductory Lesson, "The Humanism of Science", built around "the long-term programme of our Party" which was "vigorously implemented by the current Five-Year Plan" (S. Dörr, R. Surdulescu, M. Tatos 5). Introductory Lesson II contained as a topic for oral and written composition another excerpt form "a speech by Comrade Nicolae Ceauşescu" (S. Dörr, R. Surdulescu, M. Tatos 12). In all these cases, English was abused, forced into the patterns of the communist Newspeak, while such teaching came counter to the principle according to which a language is taught in its cultural context. This was also Orwell's 
conclusion in „Politics and the English Language” - "when the general atmosphere is bad, language must suffer", with a specific reference to dictatorships which cause language to deteriorate (Orwell 364). Despite the communist education which took precedence, pupils still loved their English classes, as the folowing confession testifies: "In all my high school years I only liked my $9^{\text {th }}$ grade English teacher. She played the guitar for us - which may well have been the reason - songs by John Lennon, she dictated the lyrics to us in English and Romanian so we could understand them, and then we all sang along. She also read us excerpts from The Catcher in the Rye by J. D. Salinger, which she lent to whoever wanted to read. It was like we were the same age, we had free conversations concerning the song lyrics or the book. Those were joyful classes of creative enthusiasm. [...] "Why can't the maths teacher play us Pythagoras's theorem on the guitar? Or hum us softly the algebra theorem? [...] Then we could sing the solutions to hard problems to Child in time" (Ghica 65-66).

The communist party leadership and the Securitate took a particular interest in controlling the young generations (Stroescu-Stînişoară 117), so that in the mid-70s the National radio set up a "youth division" to devise its so-called Third Channel (Programul 3). What was initially intended to be a new propaganda channel aired many quality programmes, including quality rock and pop music. As a secondary school and university student, Programul 3 provided my popular music education via actor and radio man Florian Pittiş's features on the likes of Pink Floyd or Bob Dylan. How Pittiş and the other radio people managed to get hold of the music they aired is quite another matter; these were usually recordings from Radio Free Europe, Radio Luxemburg, Tangiers, or Monte Carlo.

\section{THE 1980s}

In the 1980s Romania became a fiercely totalitarian state as Ceauşescu restalinized the country against the background of widespread depredations and his ever-expanding personality cult, the most irrational in the entire comunist bloc. In this context, English and French were the major victims, as Deletant notes (Deletant 29). Western culture and all foreign languages were simply banned from the media and public life. In a very short time the country became almost completely sealed from the outside, and was "largely seen as the most sinister country of the entire Soviet bloc" (Douglas-Home 186). Being "cosmopolitan" was again a serious crime, as experienced, for instance, by the editors of the Radio Vacanţa/ Radio Holidays, accused of deviating from comrade Ceauşescu's precious indications (Grigoriu 52). By the early 1980s universities offered only 25 places per year for entrants to study English. 
In 1980 - 1991 at the "Alexandru Ioan Cuza" University in Iaşi the only contact of first-year students of English with the language as spoken by natives was via Professor Dorobăţ's tapes during the practical courses; no wonder then that many students had trouble understanding colloquial spoken English. It should be pointed out however that in that sinister general atmosphere, English Studies at the "Alexandru Ioan Cuza” University were not unlike an oasis in the desert. Professor Dorobăţ's lectures on the beginnings of English literature and Professor Vereş's on Victorian literature were not only captivating; they were also the escape from the aggressive Newspeak/ wooden language that had taken over - "the Ceauşescu age"; "the highly human communist activity"; "the giant political-ideological level representing the communist party's strength"; and "the future builders of socialism and communism". Similarly, the Old English lectures begun by Professor Fröhlich and continued by Professor Poruciuc, were centuries away from the communist propaganda. Luckily, the faculty included excellent teaching staff. Among them Professor Hulban, who was up to date with Chomskyan linguistics, so that we were able to study all the language subjects, lexicology, morphology and syntax, in the framework of the then transformational-generative grammar which for me, mathematically-minded, was pure joy. This is reminiscent of linguist Steven Pinker's confessions concerning the beauty of grammar made about a decade later: "Grasping grammatical theory provides an intellectual pleasure that is rare in the social sciences”. (Pinker 104)

In the early 1980s our teaching staff included the very last English lecturer, William Atkinson, who told us one day that his government had decided not to send any more lecturers to Romania as they feared they would starve. The U.S. government appears to have been less concerned, since we had three American lecturers in all, Frank L. Day, who in May of 1981 presented me with my first American dictionary, a Scribner Bantam, which is still in my possession, Thomas P. Walsh and Stephen Warner. Unbeknownst to us, "all the foreign lecturers were spied on, their telephones tapped, their letters opened, their conversations reported, and their movements noted" (Lawson). Upon graduation, the rather primitive invitation addressed to our professors to join us for a final lecture plus the customary dinner reveals that in 1984 there were 23 women graduates plus one man, Sorin Antohi, to 23 teaching staff. Despite everything, of course, as is known, one's student years are the best years of one's life.

Bucharest, as the country's capital, held additional chances of escape, a major one in the shape of the British Library, described in 1985 by a Romanian poet as "a veritable cornucopia of delights" (Townson 5) and visited by 115 people daily despite the stringent security checks and the cramped conditions; there were also film sessions every night. "Young and 
old flocked to the door each morning and many stayed all day. My abiding memory is of a line of teenagers, still wearing fur hats, squashed tightly together to share the headphones of a Sony Walkman. They listened intently to David Bowie whilst watching John Cleese in Fawlty Towers whilst reading the Daily Mail whilst eating a British Embassy cheese sandwich... whilst smiling ear to ear”, reminisced Christine Melia, Assistant Representative in the late 1980s (qtd in Townson 7-8).

The British Library in Bucharest provided "the most persuasive evidence of cultural activity", attracting increasing numbers of users each year (Deletant 29). In their book The Story of English, Robert McCrum, William Cran and Robert MacNeil note that "from the earliest times it [English] was naturally the language of protest and dissent, the language of the many rather than the few. Its genius was, and still is, essentially democratic. It has given expression to the voice of freedom” (Deletant 44). These remarks were certainly true in communist Romania, where English gave expression to the voice of freedom.

\section{CONCLUSIONS}

One of Herta Müller's extensive meditations on language is titled In jeder Sprache sitzen andere Augen (every language contains a different pair of eyes). Reading and speaking in another language means living in that culture, which in adverse circumstances is also a way of escape. For translator Antoaneta Ralian, for instance, who in over sixty years translated 125 books from English into Romanian and met and befriended writers including Iris Murdoch, Saul Bellow, Ted Hughes and Kurt Vonnegut, "translation is a way of escape, a cure-all" (Ralian 202), a remark not unlike that made by Romanian-born American author and academic Andrei Codrescu, who suggests that translation can be "self-therapy" (Codrescu 101). From my own point of view, as a teenager in communist Romania, learning and studying English created a breach in what was otherwise an oppressive monotonous life, allowing me to find myself through the eyes of the English language. During the entire communist period, English, the language in which right, wrong, fair and reasonable are key words and concepts (Wierzbicka vii-viii), was engaged in a struggle with ideology and the entire social edifice built on disinformation and lies.

The role that English played behind the Iron Curtain has to be finally recognized, while the other roles that various theorists have assigned to it - a "killer" language (Skutnabb-Kangas 1998), "slayer" language (Lewis) or "hydra" (Rapatahana \& Bunce) should be analysed much more dispassionately, since "the spread of English and the loss of smaller languages are indeed connected, but not in a causal way" (Graddol "The 
Future of English" 47; see also Mufwene 2001). "The power of English, then", writes Braj B. Kachru, "resides in the domains of its use, the roles its users can play, and - attitudinally - above all, how others view its importance. On all these counts, English excels other world languages" ("The Alchemy of English" 317).

\section{Works Cited}

Bîtfoi, Doru-Liviu. Aşa s-a născut omul nou. În România anilor 1950. Bucureşti: Compania, 2012. Print.

Bourdieu, Pierre. Language and symbolic power. Cambridge, MA: Harvard University Press, 1991. Print.

Burakowski, Adam. Dictatura lui Nicolae Ceaușescu 1965-1989. Geniul Carpaților. Iași: Editura Polirom, 2011. Print.

Cantuniari, Mihai. Bărbatul cu cele trei morţi ale sale. Bucureşti: Humanitas, 2007. Print.

Cărtărescu, Mircea. Bob Dylan. Suflare în vînt. București: Humanitas, 2012. Print.

Churchward, L.G. The Soviet Intelligentsia. An Essay on the Social Structure and Roles of Soviet Intellectuals During the 1960s. London \& Boston: Routledge \& Kegan Paul, 1973. Print.

Codrescu, Andrei. "Writing Without the Enemy: The First Postrevolutionary Issue of România literară". In The Muse Is Always Half-Dressed in New Orleans and other essays, 94-103, New York: Picador USA, 1993. Print.

Costin, Miron. Stacana. Triptic cu Ahoe şi Toma Caragiu. Bucureşti: Meteor Press, 2009. Print.

Crystal, David. English as a Global Language ( $2^{\text {nd }}$ ed). Cambridge University Press, Cambridge, 2003. Print.

Decuble, Gabriel H. "Communism, walk with me!" Introduction to Cartea roz a comunismului vol.1. Iaşi: Versus, 2004. 7-14. Print.

Deletant, Dennis. "Good wine needs a bush: The British Council and Romania, 1937 to 1990". British Council. The Long and Winding Road. Recollections from our 75 years in Romania. Ed. Nigel Townson. British Council. 2013. 11-30. Print.

Doboş, Daniela. "On the Beginnings of English Studies at the University of Iaşi". Tradiţie şi modernitate în Iaşul literaturii şi lingvisticii româneşti. Ed. Mariana Flaişer. Colecţia Agora Academica 5. Iaşi: Demiurg, 2008. 130-136. Print.

Dorobăţ, Dumitru. "English Studies at "Alexandru Ioan Cuza" University of Iaşi". American, British and Canadian Studies vol. 14. Eds. Suman Gupta \& AnaKarina Schneider. Sibiu: Lucian Blaga University Press, 2010. 10-25. Print.

Douglas-Home, Jessica. A fost odată, in alte vremuri. Bucureşti: Humanitas, 2001. Print.

Gheorghiu, Mihnea. "Un Shakespeare al oamenilor”. In Shakespeare. Opere vol.I. Bucureşti: E.S.P.LA, 1955. 5-50. Print.

Ghica, Cristian. ROCKescu. București: Ed. România Pur şi Simplu, 2014. print.

Graddol, David. The Future of English? London: The British Council, 1997. Print.

Graddol, David.”The Future of English as a European Language”. The European English Messenger X/2 (2001): 47-55. Print. 
Graddol, David. English Next. London: The British Council, 2006. Print.

Grigoriu, Paul. Cutele şi cutrele memoriei. 2008-1969-2008. Bucureşti: Publica, 2015. Print.

Ionescu, Doru. Club A. 42 de ani. Muzica tinereţii tale. Bucureşti: Casa de pariuri literare, 2011. Print.

Kachru, Braj B. "World Englishes: Agony and Ecstasy". The Journal of Aesthetic Education Vol. 30/ 2 Special Issue: Distinguished Humanities Lectures II, (1996): 135-155. Print.

Kachru, Braj B. “The Alchemy of English”. The Routledge Language and Cultural Theory Reader. Eds. Lucy Burke, Tony Crowley and Alan Girvin. London \& New York: Routledge, 2000. 317-329. Print.

Kerim, Silvia. Vedere din Parfumerie. Bucureşti: Du Style, 1997. Print.

Kramsch, Claire. Context and Culture in Language Teaching. Oxford: Oxford University Press, 1993. Print.

Lawson, Christopher. “The Securitate and me”. Web. 29 September 2017. http://yourcomco.com/weblog/the_securitate_and_me_-_dec.html

Leviţchi, Leon. „Autoportret”. Leon Leviţchi. Ed. G. C. Sandulescu. Bucureşti: Contemporary Literature Press, 2013. 4-12. Print.

Lewis, P. H. "Too late to say 'extinct' in Ubykh, Eyak or Ona: Thousands of languages are endangered”. New York Times, 15 August, B7. 1998. Web.

McCrum, Robert, R. MacNeil and W. Cran. The Story of English. London: faber and faber, 2002. Print.

Mihăilescu, Dan C. „Cu ce să rimeze Kintyre dacă nu cu higher, fire \& desire?”. De la Waters la Similea. Oameni cool scriu despre muzica lor. Ed. Radu Paraschivescu. Bucureşti: Humanitas, 2013. 99-109. Print.

Mufwene, Salikoko S. The Ecology of Language Evolution. Cambridge: Cambridge University Press, 2001. Print.

Mufwene, Salikoko S. "Colonization, Globalization, and the Future of Languages in the Twenty-First Century”. Web. 14 September 2017.

http:// humanities.uchicago.edu/faculty/mufwene/mufw_colonization.html

Müller, Herta. “In jeder Sprache sitzen andere Augen“. Web. 28 September 2017. http://www.lyrikwelt.de/gedichte/muellerhertag2.htm

Orwell, George. "Politics and the English Language". The Orwell Reader. New York: Harcourt \& Brace, 1956. 355-366. Print.

Pennycook, Alastair. "Development, culture and language: ethical concerns in a postcolonial world” 1999. Web. 10 September 2017.

http://www.languages.ait.ac.th/hanoi_proceedings/pennycook.htm

Pinker, Steven. The Language Instinct. How the Mind Creates Language. New York: Harper Perennial, 1995. Print.

Protopopescu, Dragoş. Gramatica vie a limbei engleze. Ediţie facsimil îngrijită de C. George Sandulescu şi Lidia Vianu, ix-xxi. Bucureşti: Contemporary Literature Press, 2011. Print.

Ralea, Mihai. „Raport asupra atitudinii intelectualilor faţă de regim şi a calităţii producţiei intelectuale". Intelectualii români în arhivele comunismului. Ed. Dan Cătănuş. Bucureşti: Nemira, 2006. 111-159. Print. 
Ralian, Antoaneta. Nu cred în sfârşitul lumii. Articole, amintiri, interviuri. Bucureşti: Editura Art, 2016. Print.

Rapatahana, Vaughan and Pauline Bunce, eds. English language as hydra: Its impact on non-English language cultures. Bristol: Multilingual Matters, 2012. Print.

Seidlhofer, Barbara. "Brave new English”. The European English Messenger X/1 (2001): 42-48. Print.

Skutnabb-Kangas, Tove. "Human rights and language wrongs - a future for diversity?”. Language Sciences 20(1) (1998): 5-28.

Stroescu-Stînişoară, Nicolae. Povestea Europei Libere. Bucureşti: Ed. Vremea, 2015. Print.

Tismăneanu, Vladimir. Lumea secretă a nomenclaturii. Amintiri, dezvăluiri, portrete. Bucureşti: Humanitas, 2012. Print.

Townson, Nigel. British Council. The Long and Winding Road. Recollections from our 75 years in Romania. Ed. Nigel Townson. British Council, 2013. Print.

Urma, Sergiu Viorel. Dansând cu generalii. Bucureşti: Cartea Românească, 2017. Print.

Velimirovici, Felician. „De ce nu ți-ai văzut de istorie?” („Bibliotecarul”, sau despre opțiunea de a trăi în adevăr în România comunistă”). Politici culturale şi modele intelectuale în România. Eds. Lucian Nastasă and Dragoş Sdrobiş. Cluj-Napoca: Ed. Mega, 2013, 394-425. Print.

Vianu, Lidia. "Predarea limbii engleze pentru români, azi: între imitarea prin conversaţie şi predarea inteligentă”. Web. 3 October 2016.

http://rseas.ro/predarea-limbii-engleze-pentru-romani-azi-intre-imitarea-princonversatie-si-predarea-inteligenta/

Volceanov, George. „Meridiane: Despre iţele încâlcite ale canonului shakespearian”. România literară 12 (2015). Web. 20 September 2017. www.romlit.ro > Home > Arhivă > 2015 > Numarul 12

Wierzbicka, Anna. English: Meaning and Culture. Oxford: Oxford University Press, 2006. Print. 